\title{
Chapter 3 \\ On Women and Beasts: Human-Animal \\ Relationships in Sixteenth-Century \\ Thought
}

\author{
Anna Becker
}

\begin{abstract}
The chapter traces how early modern writers of political theory, often in their comments on Aristotle, viewed the relationships between some animals and humans, notably in the household. Remarkably, not all authors drew a sharp contrast between the human male on the one side, and disenfranchised women, slaves, and animals, on the other. Some writers did not view humans as completely alienated from their animal nature. Thus, early modern writers' contemplation of the human animal and the fluidity between nature and culture might inspire current reflection on animal welfare and rights.
\end{abstract}

We are used to the view that historically "what counted as fully human always depended (...) on a sharp contrast with "the animal"'. As a consequence, we might think that 'women and slaves, in being denied full humanity, were therefore necessarily partaking in animal nature'. This chapter questions the view that early modern philosophers worked with a simple analogy of women and beasts. The chapter traces how some early modern thinkers defined the relationship of human beings to animals generally, and, more particularly, how they saw the relationship of women, slaves, and animals in the human household. The picture presented, while being far from complete, shows that fifteenth- and sixteenth-century thinkers had

Revised version of the original published article "On Women and Beasts: Human-Animal Relationships in Sixteenth-Century Thought" by Anna Becker, American Journal of International Law Unbound, Volume 111, 2017, pp. 262-266. The original article was published as an Open Access article, distributed under the terms of the Creative Commons Attribution licence (http://creativecommons.org/licenses/by/4.0/)

${ }^{1}$ Tanasescu, Environment, political representation, and the challenge of rights: speaking for nature 2016, 65.

\footnotetext{
A. Becker (ه)

Aarhus University, Department of Philosophy and History of Ideas, Aarhus, Denmark e-mail: anna.becker@cas.au.dk

A. Peters (ed.), Studies in Global Animal Law, Beiträge zum ausländischen öffentlichen Recht und Völkerrecht 290, https://doi.org/10.1007/978-3-662-60756-5_3
} 
nuanced arguments to offer, when discussing the relationship of human animals to non-human animals, as well as a complex reading available on what we would regard as the relationship of 'nature' to 'culture' more broadly speaking. ${ }^{2}$ What is more, as we shall see, the equation of women with animals and slaves was not something that we commonly find in sixteenth-century philosophical treatises, which might lead us to rethink our own ideas on the relationship of one disenfranchised group with the other.

In the first book of the Politics, Aristotle described how we come to be political animals 'in a sense in which the bee is not or any gregarious animals'. ${ }^{3}$ Human beings differed from animals because they possessed speech and reason. ${ }^{4}$ Those qualities made human beings form cities and households, both very 'human' forms of society. Even gregarious animals were not thought to come together in a wellordered family life. Such a well-ordered human household, Aristotle argued, was formed out of two original societies or associations of command and obedience. It consisted of the society of husband and wife for the procreation of future generations, and of the society of master and slave for the day-to-day securing of subsistence. When Aristotle introduced his thoughts on households he underlined his argument with a quote from Hesiod's Work and Days:

From these two partnerships then is first composed the household, and Hesiod was right when he wrote 'Get first a house and a wife and an ox to draw the plough'. (The ox is a poor man's slave). This (...) is the household, the members of which Charondas calls 'bread-fellows' and Epimenides the Cretan 'stable-companions.

What was human was characterised by distinguishing it from the animal, but the animal was seen as part of the very human household. In early modern Europe, philosophers took the Aristotelian argument seriously and discussed its implications. In his 1587 commentary on the Politics, the Ferrarese professor for natural philosophy, Antonio Montecatini (1537-1599), took up Hesiod's quote. He wrote that a 'perfect' household consisted of two societies, the 'marriage society and the masterservant society'. For a master-servant association to be perfect, then, it was 'sufficient' (sanum) as Hesiod had written, to have 'at once with the wife an ox; and certainly Hesiod meant the ox to be the servant. Because the ox plays the role of the servant in the households of the poor and especially that of the peasants. By all means it is the farmer's partner and aid (socius et minister). ${ }^{6}$

\footnotetext{
${ }^{2}$ In recent years, animal-human studies have emerged as an influential field of research in the humanities and in the social sciences. For an overview of the links between feminist scholarship and human-animal studies, see Birke, 'Intimate Familiarities?' 2002, 429-436. For one example of a nuanced depiction of animal-human relationship in early modern European texts, see Fudge, Brutal Reasoning: Animals, Rationality, and Humanity in Early Modern England 2006.

${ }^{3}$ Aristotle, The Politics 1992, 1253a7, 60.

${ }^{4}$ Ibid.

${ }^{5}$ Ibid., 1252b9, 58.

${ }^{6}$ Montecatini, In politica hoc est in civiles libros Aristotelis Antonii Montecatini ferrariensis progymnasmata 1587, 29.
} 
The very human institution of the household, for Montecatini, could be called perfectly instituted when it consisted of a fellowship of human beings with animals. Animals hence were able to take the place of a human being. In this case the animal was characterised as socius, as partner, and as associate in the family realm, which it perfected. Montecatini made certain that his readers understood that, in its function as servant, the ox did not only share in the 'abstract' conceptual space of the household but also in its concrete and material space. Epimenides had called the household members 'stable companions', Montecatini argued, because 'they were eating at the same crib and from the same table'. ${ }^{7}$ The perfect household was a space in which animals worked in humans' stead, a space in which human beings shared with animals their food and their lives.

It is of course true that Aristotle had talked about the slave-master relationship as a household relationship that was characterised by a sharp hierarchy. The slave was an unfree human being without any political rights, dependent on the will of the master (who needed however treat the slave in concordance with the overall good of the household). ${ }^{8}$ This indeed might suggest that substituting the animal for the slave does not make a difference in terms of their juridical and philosophical positions. This is however not to the point. A slave, in the Aristotelian universe, is still a human being and seen from that perspective, exactly not an animal. We should also further note that in the context Montecatini was writing it is clear that he thought of the agricultural family of his own time, in which servants, not slaves were the human help. That Montecatini called the animal socius et minister, finally, shows that what was focused on here was not a 'degradation' of a human being into the position of an animal, but an 'elevation' of the animal into the position of a human being, as a companion to a human in the pursuit of every-day life.

While the animal could stand in for a slave or servant, early modern Aristotelian commentators were careful not to conflate 'woman' with 'animal', or, more precisely in this case, wife with ox. According to Aristotle in the Politics, it was a sign of barbarism to treat wives as slaves. Early modern commentators extended this further and showed that even worse was when wives were used as animals. Montecatini wrote:

In our time chiefly the wives of the Germans and the Helvetians serve their husbands, while they travel with them, and they carry heavy loads. It is as if they were slaves, or rather, as if they were mules. They carry inhuman burdens. The laws of the Mohammedans and their worshippers have wives not for slaves but for animals. ${ }^{9}$

Protestants and Muslims hence showed their considerable difference to those of the right faith in the way they treated their wives - as animals. Equating wives with animals was a sign of a life not lead morally well. It showed an unfavourable difference in religion, in civilisation, and in culture. It was a marker for strangeness. Even the most foundational unit of human life, the household, for Aristotelians was

\footnotetext{
${ }^{7}$ Ibid., 31 .

${ }^{8}$ See Aristotle, The Politics 1992, 1254a9, 65.

${ }^{9}$ Montecatini, In politica 1587, 27.
} 
not ordered according to one universal nature. 'Culture' determined what form family life took, cultural identity formed the relationships at the level of individual households.

This idea about civilisation, culture, and the 'right' life could also be turned against the very culture and religion that it ordinarily defended. One example of this can be found in 'El Inca' Garcilaso de la Vega's Comentarios Reales de los Incas (1606). 'El Inca', born 1539 in Peru as the son of an Inca princess and a Spanish conquistador, wrote the most famous history of the conquest. His work was not only a historical account but also a political treatise that defended the authority of the Inca and argued that mestizos were far more capable to rule the 'New World' than Spaniards could ever be. ${ }^{10}$ Throughout his work Garcilaso played on classical references, using tropes from Greek philosophy and Roman rhetoric, and subverted them to great effect. He argued that the Inca had erected a second Rome (otra Roma), and had managed to do so without the exploitation of animals. In vivid detail he described the instance oxen first came to Peru in 1551. The Inca observers, he wrote, 'said that the Spaniards, who were drones, and would not work themselves, had made these great Animals labour and doe that work which they ought to have performed themselves'. ${ }^{11}$ Garcilaso here turned up-side down the known trope of animals as servants. Using an animal to work on the field did not signify the cultural superiority of the conquistadors but in the eyes of the Inca rather the opposite: corruption, idleness, and laziness, and as such attributes normally assigned to the Inca by the Spanish.

Returning to the topic of the animal-woman relationship, my point here is to show that early modern humanists did not operate with a simple binary in which 'disenfranchised' beings, i.e. animals, women, and slaves, were on one side and the human male (as creation's crown) on the other. Early modern Aristotelian philosophy clearly saw both women and slaves as human beings, and as such different to animals. Neo-stoic thought had emphasised that all human beings were bound together in a cosmopolitan fellowship. From this shared humanitas however, did not flow civil rights; and the idea of the common humanity was not at all incompatible with strict hierarchical thinking in legal terms. In early modern European cities it was status that determined the civic rights of every person. The laws, privileges, and duties of early modern personhood were dependent on a myriad of different categories. This was not a matter of 'man' or 'woman'. Rather, patres familias, mothers, widows, married men, unmarried women, servants, and maids all had different civic standings. ${ }^{12}$ Granted, all human beings were different from animals, but the extent of the difference, or the distance that separated one specific

\footnotetext{
${ }^{10}$ Becker, 'Fragile Männlichkeiten?' 2017, 249-261.

${ }^{11} \mathrm{de}$ la Vega, The royal commentaries of Peru, in two parts 1688, 9, XVII, 378.

${ }^{12}$ On issues of legal standing, status, and citizenship of women in early modern Europe see e.g. Kirshner, Marriage, Dowry, and Citizenship in Late Medieval and Renaissance Italy 2015 and Kuehn, Family and Gender in Renaissance Italy, 1300-1600 2017.
} 
animal from one specific human being shifted, both according to the legal position of the human being, and according to the hierarchical position of the animal.

Indeed, the Latin word animal was used more frequently to describe human beings than non-humans. Sixtus Birck (1501-1554) defined human beings as 'social animals, bipeds', clearly here underlining what human and non-human animals had in common rather than emphasising what divided them. ${ }^{13}$ When early modern humanists wanted to make a particular point about non-human animals (rather than speaking of 'creatures' in a broad sense), they used the term bellua, beasts, that were then divided into tame (domesticated) and wild beasts, which could be divided into even more subcategories. ${ }^{14}$ The Holy Script, too, divided animals into 'the fish of the sea', 'the foule of the heaven', and 'the beast of the fielde'. ${ }^{15}$ Even between animals, there was thus a hierarchy in terms of their power relationship to human beings. Keeping in mind that human society was deeply hierarchical, it is fitting that 'animals' also were split into many different sub-categories.

It is in the context of the wild against the tame that we find, as the sixteenth century drew to a close, the equation of women with animals. In the Francogallia (1573), a work that argued that France traditionally had a constitutional past and that French citizens had the right to overthrow any king who turned out to be a tyrant, the author, François Hotman, described female rulers as indomitus, that is, as 'untamed' animals as well as 'unbridled beasts' ${ }^{16}$ Hotman $(1524-1590)$ thereby indicated that women who aimed to rule behaved like wild beasts, irrational, dangerous, and bloodthirsty. A male tyrant was bad enough; a female tyrant was nothing less than a raging animal. She had left her natural and well-ordered domain, the household, for a brutish habitat. This trope, however, was far from persistent. In the Protestant imagery of the eighteenth century it often was the woman who was seen as the civilising influence over men who, in turn, were described as having sexual appetites like wild beasts. ${ }^{17}$

Renaissance authors discussed in more detail what 'made' wild animals become tame. Some ancient authors had actually suggested that the current state of animalhuman relations was not simply due to the natural order. They argued that in the past there must have been a sort of pact between animals and human beings, which made animals obey human rule. In Lucretius' De rerum naturae, widely received in Renaissance political thought and supporting a non-anthropocentric world view, readers could find an example on how that pact might have come into being. Lucretius had argued that the dangers emanating from sharing life in the wild with beasts must have been the greatest motivator for human beings to originally form associations and so escaping a 'brutish', uncivilised situation. Hand in hand with the

\footnotetext{
${ }^{13}$ Birck/of Rotterdam/Amerbach/Maturanzio, De officiis Commentarii, 1562, 9v.

${ }^{14}$ See e.g. Montecatini, In politica 1587, p. 172.

${ }^{15}$ Genesis 1:26, 2:19. See also Shannon, 'Poor, Bare, Forked' 2009, 173-74.

${ }^{16}$ Hotman, Francogallia 1972, 484.

${ }^{17}$ See e.g. Hull, Sexuality, State, and Civil Society in Germany 1996. A close investigation of the animalisation of the sexual appetites from a gendered perspective still remains to be written.
} 
development of civilisation came the pact between animals and humans, an act of reciprocity in which animals exchanged what was useful for tutelage. ${ }^{18}$ In his 1570 commentary on De rerum naturae, Denys Lambin (1520-1572) informed us that in exchange for protection, human beings profited from 'oxen, goats, horses, and asses' as beasts of burden. The animals provided their physical strength and served as means of transportation, as well as giving human beings their furs as vestments. ${ }^{19}$

With his description of a ruler-ruled relationship between animals based on reciprocity, Lambin actually came close to contemporary descriptions of monarchical rule, particularly that of an absolute ruler. The most important apologist for absolute rule, Jean Bodin (1530-1596), had, in his Six livres de la republique (1576), argued that this was exactly what a monarch ought to do: provide care, protection, and tutelage in exchange for the absolute obedience of the subjects. ${ }^{20}$

Following Lucretius amongst others, some Renaissance thinkers argued strongly that human beings could not without problems be called 'superior to beasts'. Renaissance writers, contrary to how their thought is often understood, were not at all only concerned with placing the individual in the centre of the universe. On the contrary, praise of the exalted position that human beings held in the universe was often mixed with a reminder for the readers that with the Fall human beings had brought on themselves absolute misery. A famous example of a writer denying human superiority over animals was Michel de Montaigne (1533-1592). In the longest chapter of the Essais, the Apologie de Raimond Sebond (1580), Montaigne did his best to show that human beings had no reason to claim that they were inherently better than animals.

Beasts are born, reproduce, feed, move, live and die in ways so closely related to our own
that, if we seek ... to raise our own status above theirs, that cannot arise from any reasoned
argument on our part. Doctors recommend us to live and behave as animals do. ${ }^{21}$

Montaigne also argued that animals had prudence, even a sense of justice, in the classical Ciceronian phrasing of 'rendering everyone his due'.22 Animals were intelligent, they were able to learn even complex things, they communicated with each other, they knew how to administer medicine, and they certainly were better at counting than human infants. Montaigne even denied the singularity of what was so often understood as the most human aspect of the human condition, namely the political community. What 'form of body politic [has been] more ordered [...] than that of the bees?' he asked. He went even further and claimed that

man must be restrained with his own rank within the boundary walls of this polity; the wretch has no stomach for effectively clambering over them: he is trussed up and bound subject to the same restraints as the other creatures of his natural order. ${ }^{23}$

\footnotetext{
${ }^{18}$ Lucretius, On the nature of things 1948, V, II 860-77, 214-15.

${ }^{19}$ Lambin, T. Lucretii Cari De Rerum Naturae Commentarii 1570, 479.

${ }^{20}$ Bodin, Les Six Livres de la République 1986, I, 6, 141.

${ }^{21}$ de Montaigne, The Complete Essays 2003, 524.

${ }^{22}$ Ibid., 525.

${ }^{23}$ Ibid., 514
} 
He thus showed that the natural habitat of human beings was no different in character from the natural habitat of animals. Thereby he situated human beings very directly into their own nature: The polity was to humans what the jungle or steppe was to animals: their natural habitat. Animals were not easily able to leave their natural surroundings without giving up their nature, but neither were human beings. Beasts and human beings might live in different places, but they were still obeying the same rules in relation to these places. This shared condition did not allow for the claim of superiority of the one over the other.

Some 50 years earlier Niccolò Machiavelli (1469-1527) had actually suggested a way that human beings could 'climb over' the wall of the polity. He praised Achilles and 'many other ancient rulers' who were raised by Chiron the centaur, because 'having a mentor who was half-beast and half-man signifies that a ruler needs to use both natures and that one without the other is not effective'. To be successful, Machiavelli argued, a ruler must know 'how to act like a beast' and needed to fashion himself to be like lion and fox. ${ }^{24}$ Only if rulers were able to liken themselves to animals they would be able to withstand the dangers governing brought with it and could hope to successfully maintain their governments. Clearly the best ruler needed to know how to be both: human and beast.

The above analysis suggests that early modern thinkers did not have one binary world view, but were thinking of the relationship between some non-human animals and some human beings as changing and shifting. Renaissance thinkers assumed that human beings and animals shared very similar origins. In the Digest Ulpian had laid down that the natural law is

that which nature has taught to all animals, for this law is not peculiar to the human race, but
applies to all creatures. Hence arises the union of the male and the female which we call
marriage; and hence are derived the procreation and the education of children; for we see that
other animals also act as though endowed with knowledge of this law. ${ }^{25}$

As Annabel Brett has shown, the idea that this constituted 'a society of law' with animals was mainly denied by early modern commentators, while, on the other hand, they also never claimed that human beings were completely alienated from their animal nature. ${ }^{26}$ While early modern thinkers situated human beings into nature, they also understood that what seemed to be 'nature' might as well be 'culture': Human beings were political by nature, but their polities (or 'states' in modern parlance) were built in a process of civilisation. Different polities had different laws and customs, but this was often thought to reflect the diverse 'nature' of different cities. In this sense, fulfilling one's nature often needed cultivation. This, and the fact that we should rethink the relationship of one disenfranchised group to another, rather than assuming that their concerns might always be alike, might be a way that the distant past can still inspire us to think about pressing issues today.

\footnotetext{
${ }^{24}$ Machiavelli, The Prince 1988, XVIII, p. 61.

${ }^{25}$ Digest, 1.1 .3

${ }^{26}$ See Brett, Changes of state 2011, especially this chapter, and her chapter in this volume.
} 


\section{References}

Aristotle. (1992). The Politics (T. A. Sinclair, Trans.). Rev. T. J. Saunders. London: Penguin.

Becker, A. (2017). Fragile Männlichkeiten? Die Comentarios reales des Inka Garcilaso de la Vega zwischen europäischer Wissenstradition und peruanischer Selbstbehauptung. In S. Richter, M. Roth, \& S. Meurer (Eds.), Konstruktionen Europas in der Frühen Neuzeit (pp. 249-261). Heidelberg: Heidelberg University Publishing.

Birck, Sixtus/of Rotterdam, Erasmus/Amerbach, Veit/Maturanzio, Francisco/M. T. Ciceronis [...] De officiis Commentarii (Basel 1562).

Birke, L. (2002). Intimate familiarities? Feminism and human-animal studies. Society \& Animals, 10, 429-436.

Bodin, J. (1986). Les Six Livres de la République. In C. Frémont, M.-D. Couzinet, \& H. Rochais (Eds.), 6 vols. Paris.

Brett, A. (2011). Changes of state. Nature and the limits of the city in early modern natural law. Princeton-Woodstock: Princeton University Press.

de la Vega, G. (1688). The royal commentaries of Peru, in two parts (Paul Rycaut, Trans.). London. de Montaigne, M. (2003). The complete essays (M.A. Screech, Trans.). London: Penguin.

Fudge, E. (2006). Brutal reasoning: Animals, rationality, and humanity in early modern England. Ithaca, NY: Cornell University Press.

Hotman, F. (1972). Francogallia (J. H. M. Salmon, Trans.). R. E. Giesey (Ed. and Latin text), Cambridge: CUP.

Hull, I. V. (1996). Sexuality, state, and civil society in Germany, 1700-1815. Ithaca, NY: Cornell University Press.

Kirshner, J. (2015). Marriage, dowry, and citizenship in late medieval and renaissance Italy. Toronto: University of Toronto Press.

Kuehn, T. (2017). Family and gender in renaissance Italy, 1300-1600. Cambridge: CUP.

Lambin, D. (1570). T. Lucretii Cari De Rerum Naturae Commentarii. Paris.

Lucretius. (1948). On the nature of things (Cyril Bailey, Trans.). Oxford: OUP.

Machiavelli, N. (1988). The Prince (Quentin Skinner, Trans.). (Ed.), Russell Price. Cambridge: CUP.

Montecatini, A. (1587). In politica hoc est in civiles libros Aristotelis Antonii Montecatini ferrariensis progymnasmata. Ferrara.

Shannon, L. (2009). Poor, bare, forked: Animal sovereignty, human negative exceptionalism, and the natural history of king lear. Shakespeare Quarterly, 60, 168-196.

Tanasescu, M. (2016). Environment, political representation, and the challenge of rights: speaking for nature. London: Palgrave Macmillan.

Anna Becker is Professor MSO at the Department for Philosophy and History of Ideas at Aarhus University; Denmark. She has published widely on topics in early modern political thought and political culture, including political Aristotelianism, oeconomics and gender, and colonial masculinities. She was awarded the Balzan-Skinner Fellowship for Intellectual History in 2014-2015. 
Open Access This chapter is licensed under the terms of the Creative Commons Attribution 4.0 International License (http://creativecommons.org/licenses/by/4.0/), which permits use, sharing, adaptation, distribution and reproduction in any medium or format, as long as you give appropriate credit to the original author(s) and the source, provide a link to the Creative Commons licence and indicate if changes were made.

The images or other third party material in this chapter are included in the chapter's Creative Commons licence, unless indicated otherwise in a credit line to the material. If material is not included in the chapter's Creative Commons licence and your intended use is not permitted by statutory regulation or exceeds the permitted use, you will need to obtain permission directly from the copyright holder. 